\title{
Essentials of Teamcare in Randomized Controlled Trials of Multidisciplinary or Interdisciplinary Interventions in Somatic Care: A Systematic Review
}

\author{
Bengt Fridlund1,2*, Ewa K. Andersson1,3, Sidona-Valentina Bala1, Gull-Britt Dahlman1, \\ Anna K. Ekwall1', Stinne Glasdam¹, Ami Hommel1, Catharina Lindberg1,3, Eva I. Persson"1, \\ Andreas Rantala1, Annica Sjöström-Strand' ${ }^{1}$, Jonas Wihlborg', Karin Samuelson'1 \\ ${ }^{1}$ Department of Health Sciences, Lund University, Lund, Sweden \\ ${ }^{2}$ School of Health \& Welfare, Jönköping University, Jönköping, Sweden \\ ${ }^{3}$ Department of Health, Blekinge Institute of Technology, Karlskrona, Sweden \\ Email: "bengt.fridlund@ju.se
}

Received 10 November 2015; accepted 18 December 2015; published 21 December 2015

Copyright (C) 2015 by authors and Scientific Research Publishing Inc.

This work is licensed under the Creative Commons Attribution International License (CC BY). http://creativecommons.org/licenses/by/4.0/

(c) (i) Open Access

\begin{abstract}
Background: Teamcare should, like all patient care, also contribute to evidence-based practice (EBP). Randomized controlled trials (RCTs) focusing on teamcare have been performed but no study has addressed its essentials. How far this EBP has progressed in different health aspects is generally established in systematic reviews of RCTs. Aim: The aim is to determine the essentials of teamcare including the nurse profession in RCTs of multi- or interdisciplinary interventions in somatic care focusing on the stated context, goals, strategies, content as well as effectiveness of quality of care. Methods: A systematic review was performed according to Cochrane review assumptions to identify, appraise and synthesize all empirical evidence meeting pre-specified eligibility criteria. The PRISMA statement guided the data selection process of 27 articles from PubMed and CINAHL. Results: Eighty-five percent of RCTs in somatic care showed a positive effectiveness of teamcare interventions, of which interdisciplinary ones showed a greater effectiveness compared with the multidisciplinary approach $(100 \%$ vs $76 \%)$. Also theory-based RCTs presented higher positive effectiveness (85\%) compared with non-theory-based RCTs $(79 \%)$. The RCTs with positive effectiveness showed greater levels for professional-centered ambition in terms of goals and for team-directed initiatives in terms of strategy, and a significantly higher level for patient-team interaction plans in terms of content was shown. Conclusions: Teamcare RCTs are still grounded in the multidisciplinary approach having a professional-centered ambition while interdisciplinary
\end{abstract}

\footnotetext{
"Corresponding author.
} 
approaches especially those that are theory-based appear to be essential with regard to positive effectiveness and preferable when person-centered careis applied.

\section{Keywords}

Teamcare, Randomized Controlled Trial, Somatic Care, Systematic Review

\section{Introduction}

Healthcare professionals, and nurses in particular, are continuously being challenged to find evidence-based ways for improving patient care including the increase of job satisfaction and reduction of costs [1]. They also encounter increasingly well-educated patients at the same time as evidence-based recommendations include involving patients in their own care [2]. Team-practice has been generally proposed to meet these challenges, and interdisciplinary teams have in particular been more emphasized than multidisciplinary ones [3]. It can thus be important to have a common understanding of the differences between these, and the following operational difference, as proposed by Jessup, has thus been used [4]: Multidisciplinary team approaches utilize the skills and experience of individuals from different healthcare professions, with each team member approaching the patient from their own perspective. It is common for the multidisciplinary teams to meet the patient at separate individual consultations as well as regular team meetings in the absence of the patient. Multidisciplinary teams thus provide more knowledge and experience than healthcare professionals operating in isolation. Interdisciplinary team approaches integrate separate healthcare professionals into a single consultation: the patient-history taking, assessment, diagnosis, intervention and goals are conducted by the team on one occasion, together with the patient. The patient is intimately involved in his/her condition as well as the plan about the care. A common understanding and holistic view of all perspectives of the patient's care ensues in the best of cases, and is empowered to form part of the decision-making process for working towards the best patient outcome [4]. This is quite in line with increasing evidence that person-centered care interventions including the nurse profession [5] [6], which is the utmost form of patient-centered care comprising the patient's preferences [7] [8], are the most effective actions in restoring patients' health [9] [10]. Many patients are still, however, not directly involved in their own care and thus the patient's preferences are not interactively assessed for determining the optimal care recommendation on an individual basis [11].

Today's healthcare services as well as policy-making organizations emphasize the importance of evidencebased knowledge, which is essential for dealing with a clinical condition, through the resources available to healthcare professionals and their skills in using them [12]. Randomized controlled trials (RCTs) have been recommended for evaluating the effectiveness of the different teamcare interventions [13]. However, a clear discrepancy exists between everyday clinical practice and available empirical evidence about care interventions [14].

Several multi- and interdisciplinary RCT studies have been performed that aim to disseminate knowledge of how to implement the evidence-based knowledge. These start with a description of how to search for evidence through the PICOT format [15], and to form a critical appraisal of the studies available [16], but no study has so far addressed the essentials of teamcare [17]. No systematic (Cochrane) review exists comparing the multi- and interdisciplinary RCTs—comprising the nurse profession —in general, or somatic care in particular. However, a systematic review concerning the nurse profession's care effectiveness in RCTs revealed a figure of $71 \%$ [18]. Furthermore, what appears to be lacking in several RCTs of multi- and interdisciplinary care interventions is a careful specification about how the care has been performed [19]. This lack of knowledge needs to be addressed by establishing not only whether something works, but also why, for whom and in which circumstances [20]. These three aspects could be enlightened by specifying the essentials of teamcare interventions in terms of context, goal, strategy and content in general as well as the differences in efficacy in particular. Teamcare contributes to evidence and there is an obvious need for more team-designed RCTs with focus on evidence-based knowledge [21]. How far this has progressed, in terms of the level of evidence in different healthcare aspects, is usually established by systematic reviews of RCTs [16]. The aim of this systematic review was thus to determine the essentials of teamcare, including the nurse profession, in RCTs of multi- or interdisciplinary interven- 
tions in somatic care focusing on the stated context, goals, strategies, content as well as effectiveness of quality of care.

\section{Methods}

\subsection{Eligibility Criteria}

RCTs evaluating the effectiveness of teamcare interventions, comprising the nurse profession in the context of somatic care, were included. A team was defined as consisting of at least two individuals from different healthcare disciplines and only RCTs with at least one nurse in the team was included; defining nurse as a RN. In order to narrow our target area, studies in the field of women's (gynecology/obstetrics), children's (pediatrics) and mental (psychiatric) health were excluded. Patients as participants were in focus and thus studies comprising relatives were excluded. Outcome measures of main interest were patient-reported outcome measurements (PROM) [22] thus excluding studies focusing on e.g. cost analyses and healthcare professionals.

\subsection{Literature Search}

A review team of 13 researchers, experienced in somatic nursing care, performed a literature search in the databases PubMed and CINAHL between 2007 and 2011 with the following criteria: the English language as the most established international and scientific language and Randomized Control Trials. The following controlled vocabulary was used in the identification: "Medical Subject Headings (MeSH)"; "Patient Teamcare" or "Inter professional Relations" or "Multidisciplinary Teamcare" or "Interdisciplinary Communication". The literature search also excluded, with the Boolean operator NOT, the following free text words from the search: gynecology, pediatrics, pregnancy, psychiatric, psychiatry, mental, depression. A total of 323 references, found in PubMed and CINAHL after the extraction of duplications $(n=15)$, were thus available for screening.

\subsection{Systematic Data Selection Process}

A study protocol inspired by the Preferred Reporting Items for Systematic reviews and Meta-Analyses (PRISMA) statement [23] was used to guide the review team through the data extraction process. All retrieved titles and abstracts were screened to determine eligibility. Studies were excluded based on: non-RCTs, only study protocols, only pilot studies or not in English. Full-text copies of 220 publications were assessed by the review team and 183 of these were excluded based on; no nurse in the team, or non-PROM, non-teamcare, non-somatic care, non-patient-directed, non-caring actions (Figure 1).

\subsection{Quality Assessment}

The review team, under the direction of the first and last authors, abstracted information about and reviewed the publications in accordance with the well-established audit template of The Swedish Council on Health Technology Assessment [24]. The following keywords in the audit template were considered: study population, selection criteria, sample size, power calculation, randomization strategy, comparability between groups, blinding, compliance/adherence, primary outcomes, description of intervention and control care and treatment, drop-outs, primary/secondary outcome measures, efficacy/effectiveness, side effects, results, precision, bonds and disqualification. The publications were thus graded for methodological quality from low through medium to high, the latter indicating a stronger likelihood of the RCT design to generate unbiased results. Ten of the 37 publications assessed for quality were excluded due to low quality.

\subsection{Data Analysis}

The systematic review was performed in accordance with Cochrane review assumptions [25]; i.e. a transparent and replicable procedure attempting to identify, appraise and synthesize all empirical evidence meeting prespecified eligibility criteria to answer a given research question. The review team extracted the following data: context of care, goal, strategy and content of intervention. Theoretical standpoints and approaches of teamcare were reviewed, classifying teamcare as utilizing either a multi- or an interdisciplinary approach according to Jessup [4]. The effectiveness was based on the primary outcome stated in the studies. The reviewers scrutinized the extracted data independently followed by review team discussions concerning data quality until consensus 

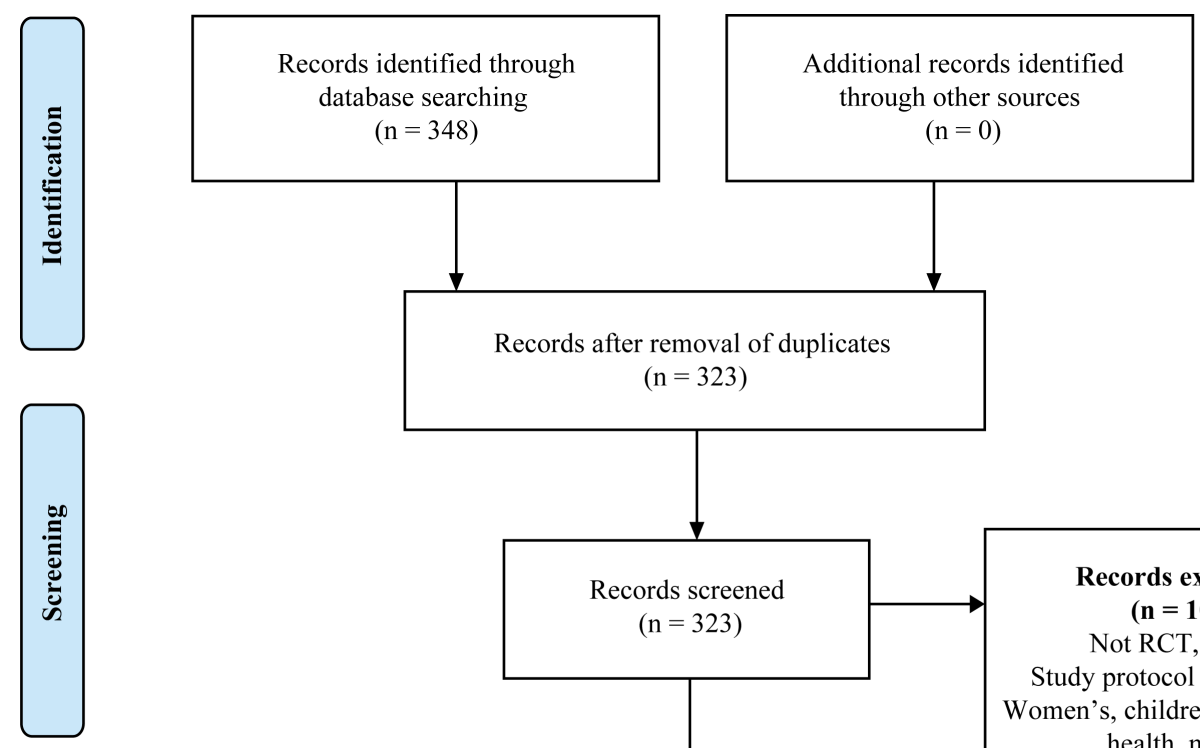

Records after removal of duplicates $(\mathrm{n}=323)$
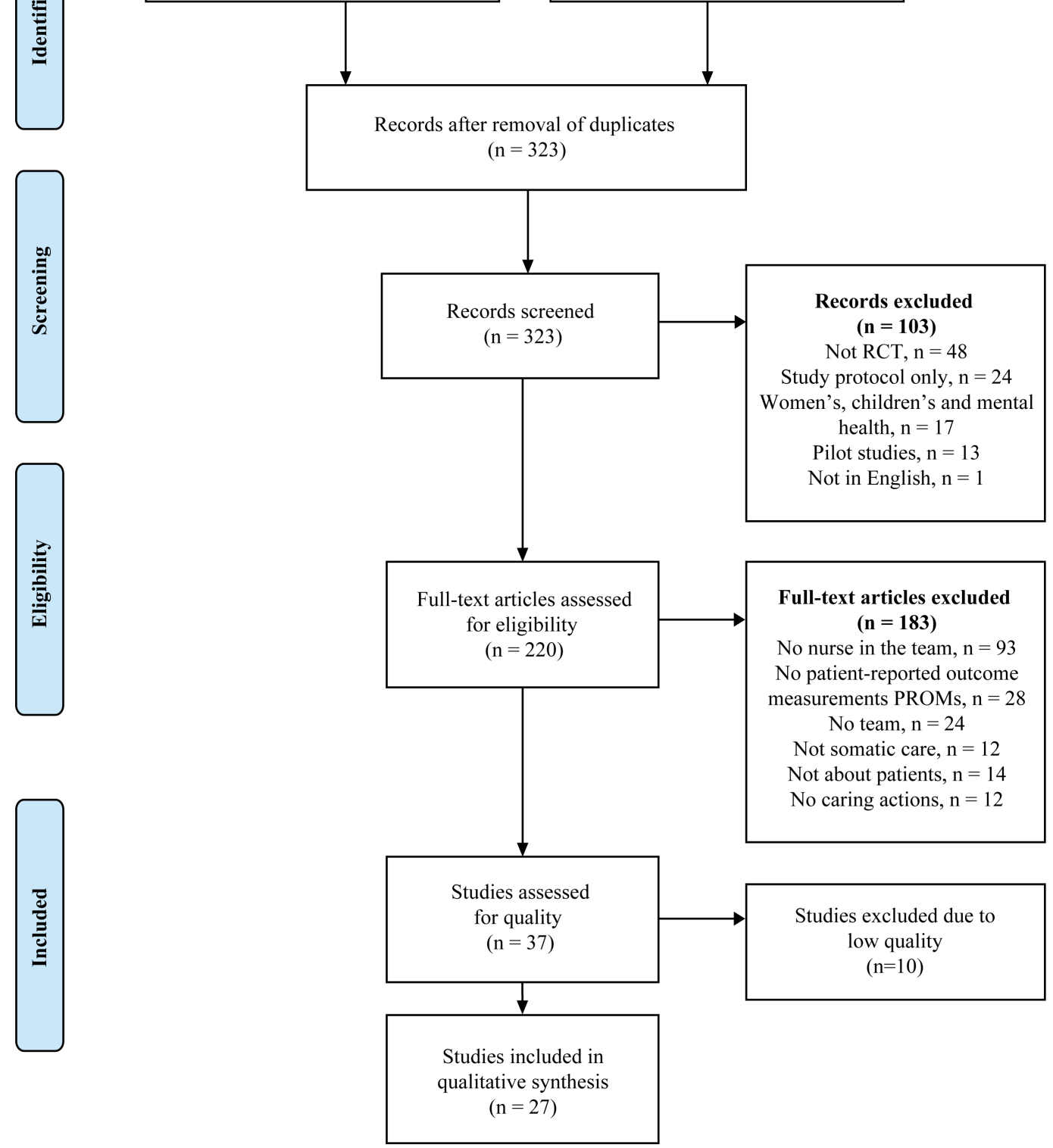

Figure 1. Flow diagram of the systematic review process.

was reached.

\section{Results}

\subsection{Demographical and Contextual Data}

Almost 90\% ( $n=24)$ of the 27 teamcare RCTs in somatic care originated in six European countries $(n=13)$ and North America $(\mathrm{n}=11)$ (Table 1). Four continents apart from Europe and North America Asia $(\mathrm{n}=2)$ and Oceania $(n=1)$ were represented. Four care contexts in somatic care were identified among the 27 RCTs: medical care $(n=14)$, which was the most common, included cardiac care $(n=6)$; surgical care $(n=5)$ comprised orthopedic care $(n=4)$; primary care $(n=5)$ and oncological care $(n=3)$. 
Table 1. Descriptive overview of the studies included $(n=27)$ : context, teamcare interventions, effects and type of teamwork.

\begin{tabular}{|c|c|c|c|c|c|c|c|}
\hline \multirow[b]{2}{*}{ Title } & \multirow{2}{*}{$\begin{array}{l}\text { Authors } \\
\text { and country } \\
\text { [ref.] }\end{array}$} & \multirow{2}{*}{$\begin{array}{l}\text { Context of care and } \\
\text { sample size (target } \\
\text { group; intervention/ } \\
\text { control) }\end{array}$} & \multicolumn{3}{|c|}{ Teamcare intervention } & \multirow{2}{*}{$\begin{array}{l}\text { Effect based } \\
\text { on primary } \\
\text { outcome }\end{array}$} & \multirow{2}{*}{$\begin{array}{l}{ }^{*} \text { Team } \\
\text { work }\end{array}$} \\
\hline & & & $\begin{array}{l}\text { Main } \\
\text { Goal }\end{array}$ & $\begin{array}{l}\text { Main } \\
\text { Strategy }\end{array}$ & $\begin{array}{l}\text { Main } \\
\text { Content }\end{array}$ & & \\
\hline $\begin{array}{l}\text { Effects of structured versus usual care on } \\
\text { renal endpoint in type } 2 \text { diabetes: the } \\
\text { SURE study: a randomized multicenter } \\
\text { translational study }\end{array}$ & $\begin{array}{l}\text { Chan } \\
\text { et al. 2009, } \\
\text { China [26] }\end{array}$ & $\begin{array}{c}\text { Medical } \\
\text { (diabetes; 104/101) }\end{array}$ & Adherence & Monitoring & Education & $\begin{array}{l}\text { Yes, reduced } \\
\text { the need for } \\
\text { dialyses }\end{array}$ & Multi \\
\hline $\begin{array}{l}{ }^{\mathrm{a}} \mathrm{A} \text { randomized controlled trial of a health } \\
\text { promotion education programme for } \\
\text { people with multiple sclerosis }\end{array}$ & $\begin{array}{l}\text { Ennis } \\
\text { et al. 2006, } \\
\text { UK [27] }\end{array}$ & $\begin{array}{l}\text { Medical (multiple } \\
\text { sclerosis; 32/30) }\end{array}$ & $\begin{array}{l}\text { Self-care } \\
\text { behavior }\end{array}$ & Self-efficacy & $\begin{array}{l}\text { Comprehensive } \\
\text { learning }\end{array}$ & $\begin{array}{l}\text { Yes, improved } \\
\text { health-promoting } \\
\text { behaviour }\end{array}$ & Multi \\
\hline $\begin{array}{l}\text { ampact of an inpatient palliative care team: } \\
\text { a randomized control trial }\end{array}$ & $\begin{array}{l}\text { Gade } \\
\text { et al. 2008, } \\
\text { USA [28] }\end{array}$ & $\begin{array}{c}\text { Medical } \\
\text { (life-limiting } \\
\text { illnesses; 275/237) }\end{array}$ & $\begin{array}{c}\text { Patient } \\
\text { satisfaction }\end{array}$ & Dialogue & Support & $\begin{array}{l}\text { Yes, greater } \\
\text { satisfaction } \\
\text { with care }\end{array}$ & Inter \\
\hline $\begin{array}{l}\text { A reengineered hospital discharge } \\
\text { program to decrease rehospitalization: } \\
\text { a randomized trial }\end{array}$ & $\begin{array}{l}\text { Jack } \\
\text { et al. 2009, } \\
\text { USA [29] }\end{array}$ & $\begin{array}{l}\text { Medical (general } \\
\text { medicine; 370/368) }\end{array}$ & Prevention & Care plans & Advice & $\begin{array}{l}\text { Yes, decreased } \\
\text { rehospitalization }\end{array}$ & Inter \\
\hline $\begin{array}{l}{ }^{\mathrm{a} C o s t l y} \text { patients with unexplained medical } \\
\text { symptoms: a high-risk population }\end{array}$ & $\begin{array}{l}\text { Margalit and } \\
\text { El-Ad, 2008, } \\
\text { Israel [30] }\end{array}$ & $\begin{array}{c}\text { Medical } \\
\text { (unexplained } \\
\text { symptoms; 21/21) }\end{array}$ & Prevention & Dialogue & $\begin{array}{l}\text { Comprehensive } \\
\text { learning }\end{array}$ & $\begin{array}{l}\text { Yes, decline in } \\
\text { visits to medical } \\
\text { settings }\end{array}$ & Multi \\
\hline $\begin{array}{l}{ }^{\mathrm{a}} \text { Multidisciplinary patient education } \\
\text { in groups increases knowledge on } \\
\text { osteoporosis: a randomized } \\
\text { controlled trial }\end{array}$ & $\begin{array}{l}\text { Nielsen } \\
\text { et al. 2008, } \\
\text { Denmark [31] }\end{array}$ & $\begin{array}{c}\text { Medical } \\
\text { (osteoporosis; } \\
141 / 128 \text { ) }\end{array}$ & $\begin{array}{l}\text { Self- } \\
\text { management }\end{array}$ & Empowerment & Education & $\begin{array}{l}\text { Yes, increased } \\
\text { patient } \\
\text { knowledge on } \\
\text { osteoporosis }\end{array}$ & Multi \\
\hline $\begin{array}{l}{ }^{a} \text { Patient education in groups increases } \\
\text { knowledge of osteoporosis and } \\
\text { adherence to treatment: a two-year } \\
\text { randomized controlled trial }\end{array}$ & $\begin{array}{c}\text { Nielsen } \\
\text { et al. 2010, } \\
\text { Denmark [32] }\end{array}$ & $\begin{array}{l}\text { Medical } \\
\text { (osteoporosis; } \\
136 / 130 \text { ) }\end{array}$ & Adherence $\mathrm{F}$ & Empowerment & Education & $\begin{array}{l}\text { Yes, increased } \\
\text { knowledge and } \\
\text { adherence to } \\
\text { treatment }\end{array}$ & Multi \\
\hline $\begin{array}{l}{ }^{\mathrm{a}} \text { A randomised controlled clinical trial } \\
\text { of nurse-, dietitian- and pedagogist-led } \\
\text { Group Care for the management of } \\
\text { Type } 2 \text { diabetes }\end{array}$ & $\begin{array}{l}\text { Trento } \\
\text { et al. 2008, } \\
\text { Italy [33] }\end{array}$ & $\begin{array}{c}\text { Medical } \\
\text { (diabetes; 25/24) }\end{array}$ & Prevention & Dialogue & $\begin{array}{l}\text { Care- } \\
\text { management }\end{array}$ & $\begin{array}{l}\text { Yes, improved } \\
\text { metabolic } \\
\text { control }\end{array}$ & Multi \\
\hline $\begin{array}{l}\text { Five-year follow-up findings from a } \\
\text { randomized controlled trial of cardiac } \\
\text { rehabilitation for heart failure }\end{array}$ & $\begin{array}{l}\text { Austin } \\
\text { et al. 2008, } \\
\text { UK [34] }\end{array}$ & $\begin{array}{l}\text { Cardiac (heart } \\
\text { failure; 57/55) }\end{array}$ & QoL & Follow-up & $\begin{array}{l}\text { Comprehensive } \\
\text { learning }\end{array}$ & $\begin{array}{l}\text { Yes, no } \\
\text { deterioration in } \\
\text { walking distance }\end{array}$ & Multi \\
\hline $\begin{array}{l}{ }^{\mathrm{a}} \text { Lessons learned from a multidisciplinary } \\
\text { heart failure clinic for older women: } \\
\text { a randomised controlled trial }\end{array}$ & $\begin{array}{l}\text { Azad } \\
\text { et al. 2008, } \\
\text { Canada [35] }\end{array}$ & $\begin{array}{l}\text { Cardiac (heart } \\
\text { failure; 45/46) }\end{array}$ & QoL & Dialogue & $\begin{array}{l}\text { Comprehensive } \\
\text { learning }\end{array}$ & $\begin{array}{l}\text { No effect on } \\
\text { heart-failure } \\
\text { specific QoL }\end{array}$ & Multi \\
\hline $\begin{array}{l}{ }^{\mathrm{a}} \text { Can a heart failure-specific cardiac } \\
\text { rehabilitation program decrease } \\
\text { hospitalizations and improve outcomes } \\
\text { in high-risk patients? }\end{array}$ & $\begin{array}{l}\text { Davidson } \\
\text { et al. 2010, } \\
\text { Australia [36] }\end{array}$ & $\begin{array}{l}\text { Cardiac (heart } \\
\text { failure; 53/52) }\end{array}$ & $\begin{array}{l}\text { Self- } \\
\text { management }\end{array}$ & Empowerment & $\begin{array}{l}\text { Comprehensive } \\
\text { learning }\end{array}$ & $\begin{array}{l}\text { Yes, reduced } \\
\text { readmissions } \\
\text { rates }\end{array}$ & Multi \\
\hline $\begin{array}{l}\text { Lack of long-term benefits of a } \\
\text { 6-month heart failure disease } \\
\text { management program }\end{array}$ & $\begin{array}{l}\text { Nguyen } \\
\text { et al. 2007, } \\
\text { Canada [37] }\end{array}$ & $\begin{array}{l}\text { Cardiac (heart } \\
\text { failure; 94/96) }\end{array}$ & Prevention & Assessment & $\begin{array}{l}\text { Disease- } \\
\text { management }\end{array}$ & $\begin{array}{l}\text { No long-term } \\
\text { effect on } \\
\text { readmissions }\end{array}$ & Multi \\
\hline $\begin{array}{l}\text { Two-year outcome of a prospective, } \\
\text { controlled study of a disease management } \\
\text { programme for elderly patients } \\
\text { with heart failure }\end{array}$ & $\begin{array}{l}\text { Sindaco } \\
\text { et al. 2007, } \\
\text { Italy [38] }\end{array}$ & $\begin{array}{l}\text { Cardiac (heart } \\
\text { failure; 86/87) }\end{array}$ & Prevention & Care plan & $\begin{array}{l}\text { Disease- } \\
\text { management }\end{array}$ & $\begin{array}{l}\text { Yes, decreased } \\
\text { number of } \\
\text { readmissions }\end{array}$ & Multi \\
\hline 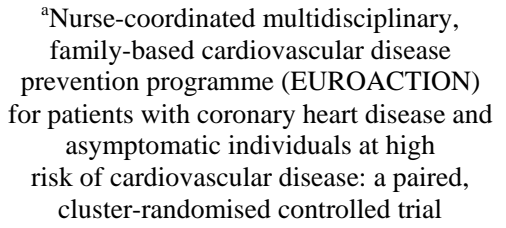 & $\begin{array}{l}\text { Wood } \\
\text { et al. 2008, } \\
\text { UK [39] }\end{array}$ & $\begin{array}{l}\text { Cardiac } \\
\text { (cardiovascular; } \\
\text { 1189/1128) }\end{array}$ & Prevention & Monitoring & Counselling & $\begin{array}{l}\text { Yes, reduced } \\
\text { risk of } \\
\text { cardiovascular } \\
\text { disease }\end{array}$ & Multi \\
\hline
\end{tabular}




\section{Continued}

The effects of guided care on the perceived quality of health care for multi-morbid older persons: 18-month outcomes from a cluster-randomized controlled trial

${ }^{\mathrm{a}}$ Geriatric care management for low-income seniors: a randomized controlled trial

Randomized controlled trial of anticipatory and preventive multidisciplinary team care: for complex patients in a community-based primary care setting

The impact of a multidisciplinary information technology-supported program on blood pressure control in primary care

Changes in walking activity and endurance following rehabilitation for people with Parkinson disease

Evaluation of a fall-prevention program in older people after femoral neck fracture: a one-year follow-up

${ }^{\mathrm{a}}$ Lack of effectiveness of a multidisciplinary fall-prevention program in elderly people at risk: a randomized, controlled trial

A multidisciplinary, multifactorial intervention program reduces postoperative falls and injuries after femoral neck fracture

Improved performance in activities of daily living and mobility after a multidisciplinary postoperative rehabilitation in older people with femoral neck fracture: a randomized controlled trial with 1-year follow-up

Will improvement in quality of life impact fatigue in patients receiving radiation therapy for advanced cancer?

Therapeutic exercise during outpatient radiation therapy for advanced cancer:

Feasibility and impact on physical well-being

${ }^{a}$ Quality of life after self-management cancer rehabilitation: a randomized controlled trial comparing physical and cognitive-behavioral training versus physical training

${ }^{\mathrm{a}}$ Fast-track in open intestinal surgery: prospective randomized study
Boyd

et al. 2010 ,

USA [40]

Counsell

et al. 2007,

USA [41]

Hogg

et al. 2009,

Canada [42]

Rinfret

et al. 2009,

Canada [43]

(hypertension;

111/112)

White

et al. 2009,

USA [44]

Berggren

et al. 2008,

Sweden [45]

Hendriks et al. 2008, the

Netherlands

[46]

$$
\begin{aligned}
& \text { Primary care } \\
& \text { (Parkinson; } \\
& \text { 35+37/35) }
\end{aligned}
$$

Orthopedic

(femoral neck

fracture; 84/76)

Orthopedic

(elderly after fall; Prevention Assessment

124/134)

Stenvall Orthopedic

et al. 2007a, (femoral neck

Sweden [47] fracture; 102/97)

Prevention Assessment

Comprehensive

, reduced

postoperative

falls

Stenvall Orthopedic

et al. 2007b, (femoral neck

Sweden [48] fracture; 102/97)

Brown

et al. 2006

USA [49]

Oncological
(cancer; 49/54)

QoL

Dialogue

Advice

Cheville

Oncological

et al. 2010,

USA [50]

49/54)

Korstjens et al. 2008, the Netherlands

Oncological

(cancer survivors; Self-manage Practical $71+76 / 62)$

ment

training

Support

Serclová et al. 2009, Czech Republic [52] $\begin{array}{cc}\begin{array}{c}\text { Surgical (intestinal } \\ \text { resection; 51/52) }\end{array} & \text { Patient } \\ \text { safety }\end{array}$
Monitoring
No effect of

fatigue

Multi

Yes, physical training improved QoL

Yes, reduced

Yes, enhanced activities of daily living performance and mobility

Yes, physical wellbeing improved at

Multi

4 week

postoperative

complications

and hospital stay
Multi and inter 


\subsection{Goals, Strategies and Content}

Forty-eight percent $(n=13)$ of the RCTs in somatic care presented a theoretical standpoint related to teamcare intervention (Table 2), with evidence-based guidelines $(\mathrm{n}=5)$ as the most common. Goals were abstracted into two main categories; a professional-centered ambition and a patient-centered ambition, with a predominance for the former of these (Table 3). The most prominent and outstanding goal with the professional-centered ambition was prevention ( $(n=11)$ while quality of life $(n=5)$ and self-management $(n=4)$ were the most common goals related to the patient-centered ambition. Strategies were abstracted into three main categories: team-directed initiatives, patient-team-directed initiatives and patient-directed initiatives (Table 3). Team-directed initiatives comprised more categories, i.e. strategies, than patient team-directed and patient-directed initiatives. The most prominent strategy for team-directed initiatives were assessment and care plans (both $n=4$ ) while the corresponding figures for patient team-directed and patient-directed initiatives were dialogue $(n=6)$ and monitoring ( $n$ $=4$ ), respectively. Contents were abstracted into two main categories (Table 3); a patient-team interaction plan and a team-management plan, the former comprising almost three times the number of categories, i.e. contents. The most common content for patient-team interaction plan was comprehensive learning $(n=9)$ while disease management $(n=4)$ and case management $(n=3)$ were the corresponding contents for the team-management plan.

\subsection{Teamcare and Its Effectiveness}

A total of $85 \%$ of the RCTs in somatic care $(n=22)$ showed positive effectiveness of a teamcare intervention, of which the interdisciplinary team had 100\% positive effectiveness (6 of 6) compared to that of the multidisciplinary team of $76 \%$ (16 of 21 ). There was a somewhat higher proportion (11 of 13; 85\%) for the theory-based RCTs in terms of positive effectiveness compared to that for the non-theory-based RCTs (11 of 14; 79\%). Furthermore, when comparing the RCT studies with positive effectivenesswith those without effectiveness, the former showed a somewhat greater level for professional-centered ambition in terms of goals and for team-directed initiatives in terms of strategy, and a significantly higher level for patient-team interaction plan in terms of content (Table 4).

Table 2. Theoretical standpoints used in the theory-based studies $(n=27)$.

\begin{tabular}{|c|c|c|}
\hline Studies & Theoretical standpoint & References used in the studies \\
\hline Hendriks et al. 2008 [46] & EBC; Prevention of falls in the elderly trial (PROFET) & Close et al. 1999 [53] \\
\hline $\begin{array}{l}\text { Nielsen et al. } 2008 \text { [31]; } \\
\text { Nielsen et al. } 2010 \text { [32] }\end{array}$ & $\begin{array}{l}\text { EBC; Guidelines for facilitating a patient } \\
\text { empowerment program }\end{array}$ & Arnold et al. 1995 [54] \\
\hline Serclová et al. 2009 [52] & EBC; ESPEN guidelines on enteral nutrition & Weimann et al. 2006 [55] \\
\hline Wood et al. 2008 [39] & $\begin{array}{l}\text { EBC; Prevention of coronary heart disease in clinical } \\
\text { practice: recommendation of the second joint task force } \\
\text { of European and other societies on coronary prevention }\end{array}$ & Wood et al. 1998 [56] \\
\hline Azad et al. 2008 [35] & Partners in care for congestive heart failure & Harrison et al. 1996 [57] \\
\hline Counsell et al. 2007 [41] & $\begin{array}{c}\text { The GRACE (Geriatric Resources for Assessment } \\
\text { and Care of Elders) model }\end{array}$ & Counsell et al. 1996 [58] \\
\hline Davidson et al. 2010 [36] & Empowerment for self-management & Grady et al. 2000 [59] \\
\hline Ennis et al. 2006 [27] & Bandura's self-efficacy theory & Bandura et al. 1977 [60] \\
\hline Gade et al. 2008 [28] & Weismann key palliative care components & Weismann et al. 1997 [61] \\
\hline Korstjens et al. 2008 [51] & Self-management and cognitive behavioral therapy & $\begin{array}{l}\text { Mesters et al. } 2002 \text { [62]; } \\
\text { Leventhal et al. } 2001 \text { [63] }\end{array}$ \\
\hline Margalit and El-Ad, 2008 [30] & Short-term family therapy in ambulatory care & Eshet et al. 1993 [64] \\
\hline Trento et al. 2008 [33] & Adult-learning & Newman et al. 2002 [65] \\
\hline
\end{tabular}

EBC = Evidence-Based Care. 
Table 3. Categorization matrix of the interventional goal, strategy and content in the studies analysed $(\mathrm{n}=27)$.

\begin{tabular}{|c|c|c|c|c|c|}
\hline \multicolumn{2}{|c|}{ Goal } & \multicolumn{2}{|c|}{ Strategy } & \multicolumn{2}{|c|}{ Content } \\
\hline Category & Main category & Category & Main category & Category & Main category \\
\hline $\begin{array}{l}\text { Prevention (11) } \\
\text { Adherence (3) } \\
\text { Patient safety (1) }\end{array}$ & $\begin{array}{l}\text { Professional-centered } \\
\text { ambition (15) }\end{array}$ & $\begin{array}{l}\text { Assessment (5) } \\
\text { Care plans (5) } \\
\text { Follow-up (1) }\end{array}$ & $\begin{array}{l}\text { Team-directed } \\
\text { initiatives (11) }\end{array}$ & $\begin{array}{l}\text { Comprehensive } \\
\text { learning (9) } \\
\text { Education (5) } \\
\text { Advice (3) } \\
\text { Support (2) } \\
\text { Counselling (1) }\end{array}$ & $\begin{array}{c}\text { Patient-team } \\
\text { interaction plan (20) }\end{array}$ \\
\hline $\begin{array}{c}\text { Quality of life (5) } \\
\text { Self-management (4) } \\
\text { Patient satisfaction (2) } \\
\text { Self-care behaviour (1) }\end{array}$ & $\begin{array}{l}\text { Patient-centered } \\
\text { ambition (12) }\end{array}$ & $\begin{array}{c}\text { Dialogue (6) } \\
\text { Empowerment (3) } \\
\text { Monitoring (4) } \\
\text { Practical training (2) } \\
\text { Self-efficacy (1) }\end{array}$ & $\begin{array}{l}\text { Patient-team-directed } \\
\text { initiatives (9) }\end{array}$ & $\begin{array}{l}\text { Disease-management (4) } \\
\text { Care-management (3) }\end{array}$ & $\begin{array}{c}\text { Team-management } \\
\text { plan }(7)\end{array}$ \\
\hline
\end{tabular}

Table 4. RCTs in somatic care with effect $(n=22)$ and without effect $(n=5)$ in relation to intervention goal, strategy and content.

\begin{tabular}{lcc}
\hline \multicolumn{1}{c}{ Intervention } & Studies with effect, $\mathrm{n}(\%)$ & Studies without effect, $\mathrm{n}(\%)$ \\
\hline Intervention goal & $12(55)$ & $3(60)$ \\
Professional-centered ambition & $10(45)$ & $2(40)$ \\
$\quad$ Patient-centered ambition & & $3(60)$ \\
\hline Intervention strategy & $8(36)$ & $2(40)$ \\
Team-directed initiatives & $7(32)$ & $0(0)$ \\
Patient team-directed initiatives & $7(32)$ & $3(60)$ \\
Patient-directed initiatives & & $2(40)$ \\
\hline Intervention content & $17(77)$ & \\
Patient team-interaaction plan & $5(23)$ & \\
Team-management plan & & \\
\hline
\end{tabular}

\section{Discussion}

\subsection{Methodological Considerations}

It is noteworthy that fewer than $10 \%$ of the identified RCTs remained for the final review process thus indicating the importance of dictating relevant inclusion and exclusion criteria as well as quality assessment, even for RCT-designs. It is also important to remember that qualitative designs are essential for identifying patients' needs in order to develop the most appropriate and effective PROM-interventions [13] [66]. A possible limitation was that only two databases were screened with regard to multi- and interdisciplinary care RCTs; but these databases were the largest and most relevant ones. Another possible limitation was to only study the phenomenon in a somatic context. It is essential from a methodological standpoint to be able to handle data correctly with sufficient review competence; this was possible in this study as all researchers were familiar with the somatic care context. Another limitation is the large review team with a potential risk for bias in the extraction and interpretation processes; but the review process was guided by an established study protocol [24] as well as the Cochrane review assumptions [25] thus entailing that each review was scrutinized by the review team-who had been supervised by two experienced nurse researchers - until a consensus was reached. There is also a risk in making correct decisions concerning effectiveness or not, due to the studies' choice of primary outcome and the magnitude of clinical relevance and utility from a multi- or interdisciplinary care perspective [4] [15]. The research team reflected on these possibilities until a consensus was reached. 


\subsection{Teamcare Intervention Considerations}

Considering the fact that almost all teamcare intervention studies had been carried out in Europe and North America, it is questionable how well the results can be generalized outside these continents. On the other hand the need for more teamcare interventions has been emphasized [3] [4] and this appears to be particularly true for all countries, except perhaps for the USA. It is noteworthy that one care context in somatic care stands out; medical care in general and cardiac care in particular. Cardiac care is, however, a common area engaging both clinical and academic healthcare professionals, and not least the nurse profession [67]. This is in line with the conclusions of a literature review on nurse-led RCTs in somatic care where professional interests and public resources were a major feature in this field. [18]. It is also satisfactory that as many as 85\% of the teamcare RCTs reported positive effectiveness, thus confirming previous findings [14]. However it is important to conclude that teamcare interventions appear to be more efficient compared to nurse-led interventions (85\% vs. 71\%) [18]. One relevant reason for the success of teamcare interventions is, apart from the holistic view of the patient, clearly the enhanced patient participation in the decision-making process, in terms of all the involved healthcare professionals, making the patient more motivated to make a change [4] [11]. RCTs with a person-centered care approach demonstrated relatively high positive effectiveness [10], but this literature review does not completely confirm these findings of a person-centered care approach in terms of interventional goal and strategies, which is surprising when considering the high level of positive effectiveness of 85\%. This could, however, be explained by the fact that most of the teamcare interventions were based on the multidisciplinary and not the interdisciplinary approach, which when performed correctly has "a real” holistic view thus empowering the decision-making process towards the best health outcome [3] [11]. This reasoning is supported in this literature review by the fact that the interdisciplinary approach demonstrated greater effectiveness compared to the multidisciplinary approach (100\% vs 76\%). A person-centered care is again preferable in order to empower the patient in maintaining health or preventing disease [68] [69]. Apart from the holistic perspective involving a participating patient, person-centered care also advocates the need for and use of EBP [2] [6]. Such reasoning thus highlights the importance of using theoretical standpoints when operationalizing the study design by using appropriate measurements in order to establish both relevant and effective outcomes [70]. This literature review confirms results from previous studies regarding theory-based designs (85\%) being more effective than the non-theory-based ones (79\%), but such theory-based strategies still seem premature [6] [18]. A theory-based teamcare RCT intervention thus indicates the need for a platform for planning and developing the context, goals, strategies, content as well as the essentials of an interdisciplinary approach related to desirable effectiveness.

\section{Conclusions and Implications}

Teamcare RCTs are still founded on the multidisciplinary approach having a professional-centered ambition with the team-directed initiative whilst utilizing a patient team-interaction plan. Interdisciplinary approaches especially those that are theory-based appear to be essential with regard to positive effectiveness, preferably when person-centered care is applied based on evidence-based practice. More literature reviews are needed in order to compare teamcare RCTs in somatic care with those focusing on children's and women's health as well as mental health.

\section{References}

[1] Fineout-Overholt, E., Melnyk, B.M. and Schultz, A. (2005) Transforming Health Care from the Inside Out: Advancing Evidence-Based Practice in the $21^{\text {st }}$ Century. Journal of Professional Nursing, 21, 335-344. http://dx.doi.org/10.1016/j.profnurs.2005.10.005

[2] Angel, S. and Frederiksen, K.N. (2015) Challenges in Achieving Patient Participation: A Review of How Patient Participation Is Addressed in Empirical Studies. International Journal of Nursing Studies, 52, 1525-1538. http://dx.doi.org/10.1016/j.ijnurstu.2015.04.008

[3] Nancarrow, S.A.,Booth, A., Ariss, S., Smith, T., Enderby, P. and Roots, A.(2013) Ten Principles of Good Interdisciplinary Team Work. Human Resources for Health, 11, 19. http://dx.doi.org/10.1186/1478-4491-11-19

[4] Jessup, R.L. (2007) Interdisciplinary versus Multidisciplinary Care Teams: Do We Understand the Difference? Australian Health Review, 31, 330-331. http://dx.doi.org/10.1071/AH070330

[5] Leplege, A., Gzil, F., Cammellin, M, Lefeve, C., Pachoud, B. and Ville, I. (2007) Person-Centredness—Conceptual and Historical Perspectives. Disability Rehabilitation, 29, 1555-1565. http://dx.doi.org/10.1080/09638280701618661 
[6] Ekman, I., Swedberg, K., Taft, C., Lindseth, A., Norberg, A., Brink, E., Carlsson, J., Dahlin-Ivanoff, S., Johansson, I.L, Kjellgren, K., Lidén, E., Öhlén, J., Olsson, L.E., Rosén, H., Rydmark, M. and Sunnerhagen, K.S. (2011) Person-Centered Care-Ready for Prime Time. European Journal of Cardiovascular Nursing, 10, 248-251. http://dx.doi.org/10.1016/j.ejcnurse.2011.06.008

[7] Starfield, B. (2011) Is Patient-Centered Care the Same as Person-Focused Care? Permanente Journal, 15, 63-69. http://dx.doi.org/10.7812/TPP/10-148

[8] Say, R.E. and Thomsen, R. (2003) The Importance of Patient Preferences in Treatment Decisions-Challenges for Doctors. British Medical Journal, 327, 542-545. http://dx.doi.org/10.1136/bmj.327.7414.542

[9] Boivin, A., Currie, K., Fervers, B., Gracia, J., James, M., Marshall, C., Sakala, C., Sanger, S., Strid, J., Thomas, V., van der Weijden, T., Grol, R. and Burgers, J.; G-I-N PUBLIC (2010) Patients and Public Involvement in Clinical Guidelines; International Experiences and Future Perspectives. Quality and Safety in Health Care, 19, e22. http://dx.doi.org/10.1136/qshc.2009.034835

[10] Olsson, L.-E., Jakobsson Ung, E., Swedberg, K. and Ekman, I. (2012) Efficacy of Person-Centered Care as an Intervention in Controlled Trials-A Systematic Review. Journal of Clinical Nursing, 22, 456-465. http://dx.doi.org/10.1111/jocn.12039

[11] Coulter, A., Entwistle, V.A., Eccles, A., Ryan, S., Shepperd, S. and Perera, R. (2013) Personalised Care Planning for Adults with Chronic or Long-Term Health Conditions (Protocol). The Cochrane Collaboration, 5, No. CD010523.

[12] Ellen, M.E., Léon, G., Bouchard, G., Lavis, J.N., Ouimet, M. and Grimshaw, J.M. (2013) What Supports Do Health System Organizations Have in Place to Facilitate Evidence-Informed Decision-Making? A Qualitative Study. Implementation Science, 8, 84. http://dx.doi.org/10.1186/1748-5908-8-84

[13] Lewin, S., Glenton, C. and Oxman, A.D. (2009) Use of Qualitative Methods Alongside Randomised Controlled Trials of Complex Healthcare Interventions: Methodological Study. British Medical Journal, 339, b3496. http://dx.doi.org/10.1136/bmj.b3496

[14] Kilgore, R.V. and Langford, R.W. (2010) Defragmenting Care: Testing an Intervention to Increase the Effectiveness of Interdisciplinary Health Care Teams. Critical Care Nursing Clinics of North America, 22, 271-278. http://dx.doi.org/10.1016/j.ccell.2010.03.006

[15] Rios, L.P., Ye, C. and Thabane, L. (2010) Association between Framing of the Research Question Using the PICOT Format and Reporting Quality of Randomized Controlled Trials. BMC Medical Research Methodology, 10, 11. http://dx.doi.org/10.1186/1471-2288-10-11

[16] Fineout-Overholt, E., Melnyk, B.M., Stillwell, S.B. and Williamson, K.M. (2010) Evidence-Based Practice Step by Step: Critical Appraisal of the Evidence-Part I. American Journal of Nursing, 110, 47-52. http://dx.doi.org/10.1097/01.NAJ.0000383935.22721.9c

[17] Tuckett, A.G. (2005) The Care Encounter: Pondering Caring, Honest Communication and Control. International Journal of Nursing Practice, 11, 77-84. http://dx.doi.org/10.1111/j.1440-172X.2005.00505.X

[18] Fridlund, B., Jönsson, A.C., Andersson, E.K., Bala, S.-V., Dahlman, G.-B., Forsberg, A., Glasdam, S., Hommel, A., Kristensson, A., Lindberg, C., Sivberg, B., Sjöström-Strand, A., Wihlborg, J. and Samuelson, K. (2014) Essential of Nursing Care in Randomized Controlled Trials of Nurse-Led Interventions in Somatic Care: A Systematic Review. Open Journal of Nursing, 4, 181-197. http://dx.doi.org/10.4236/ojn.2014.43023

[19] Martin, J.S., Ummenhofer, W., Manser, T. and Spiriga, R. (2010) Interprofessional Collaboration among Nurses and Physicians: Making a Difference in Patient Outcome. Swiss Medical Weekly, 140, w13062. http://dx.doi.org/10.4414/smw.2010.13062

[20] Forbes, A. (2009) Clinical Intervention Research in Nursing. International Journal of Nursing Studies, 46, 557-568. http://dx.doi.org/10.1016/j.ijnurstu.2008.08.012

[21] Zwarenstein, M., Goldman, J. and Reeves, S. (2009) Interprofessional Collaboration: Effects of Practice-Based Interventions on Professional Practice and Healthcare Outcomes. Cochrane Database of Systematic Reviews, 3, CD000072.

[22] Valderas, J.M., Kotzeva, A., Espallargues, M., Guyatt, G., Ferrans, C.E., Halyard, M.Y., et al. (2008) The Impact of Measuring Patient-Reported Outcomes in Clinical Practice: A Systematic Review of the Literature. Quality of Life Research, 17, 179-193. http://dx.doi.org/10.1007/s11136-007-9295-0

[23] Liberati, A., Altman, D.G., Tetzlatt, J., Mulrow, C., Gotzsche, P.C. and Joannidis, J.P. (2009) The PRISMA Statement for Reporting Systematic Reviews and Metaanalyses of Studies That Evaluate Healthcare Interventions: Explanation and Elaborations. British Medical Journal, 339, b2700. http://dx.doi.org/10.1136/bmj.b2700

[24] Swedish Council on Health Technology Assessment (2009) Evaluation and Synthesis of Studies Using QuantitativeMethods of Analysis. SBU, Stockholm.

[25] Higgins, J.P.T. and Green, S. (2011) Cochrane Collaboration Handbook for Systematic Review of Interventions. The Cochrane Collaboration, London. 
[26] Chan, J.C., So, W.Y., Yeung, C.Y., Ko, G.T., Lau, I.T., Tsang, M.W., Lau, K.P., Siu, S.C., Li, J.K., Yeung, V.T., Leung, W.Y. and Tong, P.C., SURE Study Group (2009) Effects of Structured versus Usual Care on Renal Endpoint in Type 2 Diabetes: The SURE Study: A Randomized Multicenter Translational Study. Diabetes Care, 32, 977-982. http://dx.doi.org/10.1136/bmj.b2700

[27] Ennis, M., Thain, J., Boggild, M., Baker, G.A. and Young, C.A. (2006) A Randomized Controlled Trial of a Health Promotion Education Programme for People with Multiple Sclerosis. Clinical Rehabilitation, 20, 783-792. http://dx.doi.org/10.1177/0269215506070805

[28] Gade, G., Venohr, I., Conner, D., McGrady, K., Beane, J., Richardson, R.H., Williams, M.P., Liberson, M., Blum, M. and Della Penna, R. (2008) Impact of an Inpatient Palliative Care Team: A Randomized Control Trial. Journal of Palliative Medicine, 11, 180-190. http://dx.doi.org/10.1089/jpm.2007.0055

[29] Jack, B.W., Chetty, V.K., Anthony, D., Greenwald, J.L., Sanchez, G.M., Johnson, A.E., Forsythe, S.R., O’Donnell, J.K., Paasche-Orlow, M.K., Manasseh, C., Martin, S. and Culpepper, L. (2009) A Reengineered Hospital Discharge Program to Decrease Rehospitalization: A Randomized Trial. Annals of Internal Medicine, 150, 178-187. http://dx.doi.org/10.7326/0003-4819-150-3-200902030-00007

[30] Margalit, A.P. and El-Ad, A. (2008) Costly Patients with Unexplained Medical Symptoms: A High-Risk Population. Patient Education and Counseling, 70, 173-178. http://dx.doi.org/10.1016/j.pec.2007.09.020

[31] Nielsen, D., Ryg, J., Nissen, N., Nielsen, W., Knold, B. and Brixen, K. (2008) Multidisciplinary Patient Education in Groups Increases Knowledge on Osteoporosis: A Randomized Controlled Trial. Scandinavian Journal of Public Health, 36, 346-352. http://dx.doi.org/10.1177/1403494808089558

[32] Nielsen, D., Ryg, J., Nielsen, W., Knold, B., Nissen, N. and Brixen, K. (2010) Patient Education in Groups Increases Knowledge of Osteoporosis and Adherence to Treatment: A Two-Year Randomized Controlled Trial. Patient Education and Counseling, 81, 155-160. http://dx.doi.org/10.1016/j.pec.2010.03.010

[33] Trento, M., Basile, M., Borgo, E., Grassi, G., Scuntero, P., Trinetta, A., Cavallo, F. and Porta, M. (2008) A Randomised Controlled Clinical Trial of Nurse-, Dietitian- and Pedagogistled Group Care for the Management of Type 2 Diabetes. Journal of Endocrinological Investigation, 31, 1038-1042. http://dx.doi.org/10.1007/BF03345645

[34] Austin, J., Williams, W.R., Ross, L. and Hutchison, S. (2008) Five-Year Follow-Up Findings from a Randomized Controlled Trial of Cardiac Rehabilitation for Heart Failure. European Journal of Cardiovascular Prevention and Rehabilitation, 15, 162-167. http://dx.doi.org/10.1097/HJR.0b013e3282f10e87

[35] Azad, N., Molnar, F. and Byszewski, A. (2008) Lessons Learned from a Multidisciplinary Heart Failure Clinic for Older Women: A Randomised Controlled Trial. Age and Ageing, 37, 282-287. http://dx.doi.org/10.1093/ageing/afn013

[36] Davidson, P.M., Cockburn, J., Newton, P.J., Webster, J.K., Betihavas, V., Howes, L. and Owensby, D.O. (2010) Can a Heart Failure-Specific Cardiac Rehabilitation Program Decrease Hospitalizations and Improve Outcomes in High-Risk Patients? European Journal of Cardiovascular Prevention and Rehabilitation, 17, 393-402. http://dx.doi.org/10.1097/HJR.0b013e328334ea56

[37] Nguyen, V., Ducharme, A., White, M., Racine, N., O’Meara, E., Zhang, B., Rouleau, J.L. and Brophy, J. (2007) Lack of Long-Term Benefits of a 6-Month Heart Failure Disease Management Program. Journal of Cardiac Failure, 13, 287-293. http://dx.doi.org/10.1016/j.cardfail.2007.01.002

[38] Del Sindaco, D., Pulignano, G., Minardi, G., Apostoli, A., Guerrieri, L., Rotoloni, M., Petri, G., Fabrizi, L., Caroselli, A., Venusti, R., Chiantera, A., Giulivi, A., Giovannini, E. and Leggio, F. (2007) Two-Year Outcome of a Prospective, Controlled Study of a Disease Management Programme for Elderly Patients with Heart Failure. Journal of Cardiovascular Medicine (Hagerstown), 8, 324-329. http://dx.doi.org/10.2459/JCM.0b013e32801164cb

[39] Wood, D.A., Kotseva, K., Connolly, S., Jennings, C., Mead, A., Jones, J., Holden, A., De Bacquer, D., Collier, T., De Backer, G. and Faergeman, O., EUROACTION Study Group (2008) Nurse-Coordinated Multidisciplinary, Family-Based Cardiovascular Disease Prevention Programme (EUROACTION) for Patients with Coronary Heart Disease and Asymptomatic Individuals at High Risk of Cardiovascular Disease: A Paired, Cluster-Randomised Controlled Trial. The Lancet, 371, 1999-2012. http://dx.doi.org/10.1016/S0140-6736(08)60868-5

[40] Boyd, C.M., Reider, L., Frey, K., Scharfstein, D., Leff, B., Wolff, J., Groves, C., Karm, L.,Wegener, S., Marsteller, J. and Boult, C. (2010) The Effects of Guided Care on the Perceived Quality of Health Care for Multi-Morbid Older Persons: 18-Month Outcomes from a Cluster-Randomized Controlled Trial. Journal of General Internal Medicine, 25, 235-242. http://dx.doi.org/10.1007/s11606-009-1192-5

[41] Counsell, S.R., Callahan, C.M., Clark, D.O., Tu, W., Buttar, A.B., Stump, T.E. and Ricketts, G.D. (2007) Geriatric Care Management for Low-Income Seniors: A Randomized Controlled Trial. Journal of the American Medical Association, 298, 2623-2633. http://dx.doi.org/10.1001/jama.298.22.2623

[42] Hogg, W., Lemelin, J., Dahrouge, S., Liddy, C., Armstrong, C.D., Legault, F., Dalziel, B. and Zhang,W. (2009) Randomized Controlled Trial of Anticipatory and Preventive Multidisciplinary Team Care: For Complex Patients in a Community-Based Primary Care Setting. Canadian Family Physician, 55, e76-e85. 
[43] Rinfret, S., Lussier, M.T., Peirce, A., Duhamel, F., Cossette, S., Lalonde, L., Tremblay, C., Guertin, M.C., LeLorier, J., Turgeon, J., Hamet, P. and LOYAL Study Investigators (2009) The Impact of a Multidisciplinary Information Technology-Supported Program on Blood Pressure Control in Primary Care. Circulation: Cardiovascular Quality and Outcomes, 2, 170-177. http://dx.doi.org/10.1161/CIRCOUTCOMES.108.823765

[44] White, D.K., Wagenaar, R.C., Ellis, T.D. and Tickle-Degnen, L. (2009) Changes in Walking Activity and Endurance Following Rehabilitation for People with Parkinson Disease. Archives of Physical Medicine and Rehabilitation, 90, 43-50. http://dx.doi.org/10.1016/j.apmr.2008.06.034

[45] Berggren, M., Stenvall, M., Olofsson, B. and Gustafson, Y. (2008) Evaluation of a Fall-Prevention Program in Older People after Femoral Neck Fracture: A One-Year Follow-Up. Osteoporos International, 19, 801-809. http://dx.doi.org/10.1007/s00198-007-0507-9

[46] Hendriks, M.R., Bleijlevens, M.H., van Haastregt, J.C., Crebolder, H.F., Diederiks, J.P., Evers, S.M., Mulder, W.J., Kempen, G.I., van Rossum, E., Ruijgrok, J.M., Stalenhoef, P.A. and van Eijk, J.T. (2008) Lack of Effectiveness of a Multidisciplinary Fall-Prevention Program in Elderly People at Risk: A Randomized, Controlled Trial. Journal of the American Geriatrics Society, 56, 1390-1397. http://dx.doi.org/10.1111/j.1532-5415.2008.01803.x

[47] Stenvall, M., Olofsson, B., Lundström, M., Englund, U., Borssén, B., Svensson, O., Nyberg, L. and Gustafson, Y. (2007) A Multidisciplinary, Multifactorial Intervention Program Reduces Postoperative Falls and Injuries after Femoral Neck Fracture. Osteoporos International, 18, 167-175. http://dx.doi.org/10.1007/s00198-006-0226-7

[48] Stenvall, M., Olofsson, B., Nyberg, L., Lundström, M. and Gustafson, Y. (2007) Improved Performance in Activities of Daily Living and Mobility after a Multidisciplinary Postoperative Rehabilitation in Older People with Femoral Neck Fracture: A Randomized Controlled Trial with 1-Year Follow-Up. Journal of Rehabilitation Medicine, 39, 232-238. http://dx.doi.org/10.2340/16501977-0045

[49] Brown, P., Clark, M.M., Atherton, P., Huschka, M., Sloan, J.A., Gamble, G., Girardi, J., Frost, M.H., Piderman, K. and Rummans, T.A. (2006) Will Improvement in Quality of Life (QOL) Impact Fatigue in Patients Receiving Radiation Therapy for Advanced Cancer? American Journal of Clinical Oncology, 29, 52-58. http://dx.doi.org/10.1097/01.coc.0000190459.14841.55

[50] Cheville, A.L., Girardi, J., Clark, M.M., Rummans, T.A., Pittelkow, T., Brown, P., Hanson, J., Atherton, P., Johnson, M.E., Sloan, J.A. and Gamble, G. (2010) Therapeutic Exercise during Outpatient Radiation Therapy for Advanced Cancer: Feasibility and Impact on Physical Well-Being. American Journal of Physical Medicine \& Rehabilitation, 89, 611-619. http://dx.doi.org/10.1097/PHM.0b013e3181d3e782

[51] Korstjens, I., May, A.M., van Weert, E., Mesters, I., Tan, F., Ros, W.J., Hoekstra-Weebers, J.E., van der Schans, C.P. and van den Borne, B. (2008) Quality of Life after Self-Management Cancer Rehabilitation: A Randomized Controlled Trial Comparing Physical and Cognitive-Behavioral Training versus Physical Training. Psychosomatic Medicine, 70, 422-429. http://dx.doi.org/10.1097/PSY.0b013e31816e038f

[52] Serclová, Z., Dytrych, P., Marvan, J., Nová, K., Hankeová, Z., Ryska, O., Slégrová, Z., Buresová, L., Trávníková, L. and Antos, F. (2009) Fast-Track in Open Intestinal Surgery: Prospective Randomized Study (Clinical Trials Gov Identifier No. NCT00123456). Clinical Nutrition, 28, 618-624. http://dx.doi.org/10.1016/j.clnu.2009.05.009

[53] Close, J., Ellis, M., Hooper, R., Glucksman, E., Jackson, S. and Swift, C. (1999) Prevention of Falls in the Elderly Trial (PROFET): A Randomized Controlled Trial. The Lancet, 353, 93-97. http://dx.doi.org/10.1016/S0140-6736(98)06119-4

[54] Arnold, M.S., Butler, P.M., Anderson, R.M., Funnell, M.M. and Feste, C. (1995) Guidelines for Facilitating a Patient Empowerment Program. The Diabetes Educator, 21, 308-312. http://dx.doi.org/10.1177/014572179502100408

[55] Weimann, A., Braga, M., Harsanyi, L., Laviano, A., Ljungqvist, O., Soeters, P., DGEM (German Society for Nutritional Medicine) Jauch, K.W., Kemen, M., Hiesmayr, J.M., Horbach, T., Kuse, E.R., Vestweber, K.H. and ESPEN (European Society for Parenteral and Enteral Nutrition) (2006) ESPEN Guidelines on Enteral Nutrition: Surgery including Organ Transplantation. Clinical Nutrition, 25, 224-244. http://dx.doi.org/10.1016/j.clnu.2006.01.015

[56] Wood, D., De Backer, G., Faergeman, O., Graham, I., Mancia, G. and Pyörälä, K. (1998) Prevention of Coronary Heart Disease in Clinical Practice: Recommendations of the Second Joint Task Force of European and Other Societies on Coronary Prevention. European Heart Journal, 19, 1434-1503. http://dx.doi.org/10.1053/euhj.1998.1243

[57] Harrison, M.B., Toman, C. and Logan, J. (1996) Partners in Care for Congestive Heart Failure. 2nd Edition, Continuity of Care Study, University of Ottawa Loeb Research Institute, Ottawa.

[58] Counsell, S.R., Callahan, C.M., Buttar, A.B., Clark, D.O. and Frank, K.I. (2006) Geriatric Resources for Assessment and Care of Elders (GRACE): A New Model of Primary Care for Low-Income Seniors. Journal of the American Geriatrics Society, 54, 1136-1141. http://dx.doi.org/10.1111/j.1532-5415.2006.00791.x

[59] Grady, K.L., Dracup, K., Kennedy, G., Moser, D.K., Piano, M., Warner Stevenson, L. and Young, J.B. (2000) Team Management of Patients with Heart Failure: A Statement for Healthcare Professionals from the Cardiovascular Nursing Council of the American Heart Association. Circulation, 102, 2443-2456. 
http://dx.doi.org/10.1161/01.CIR.102.19.2443

[60] Bandura, A. (1977) Self-Efficacy: Toward a Unifying Theory of Behavioural Change. Psychological Review, 84, 191-215. http://dx.doi.org/10.1037/0033-295X.84.2.191

[61] Weismann, D. (1997) Consultation in Palliative Medicine. Archives of Internal Medicine, 157, 733-737. http://dx.doi.org/10.1001/archinte.1997.00440280035003

[62] Mesters, I., Creer, T.L. and Gerards, F. (2002) Self-Management and Respiratory Disorders: Guiding from Health Counseling and Self-Management Perspectives. In: Kaptein, A. and Creer, T.L., Eds., Respiratory Disorders and Behavioral Research, Dunitz, London, 139-174. http://dx.doi.org/10.4324/9780203221570_chapter_6

[63] Leventhal, H. and Carr, S. (2001) Speculations on the Relationship of Behavioral Therapy to Psychosocial Research on Cancer. In: Baum, A. and Andersen, B.L., Eds., Psychosocial Interventions for Cancer, American Psychological Association, Washington DC, 375-400. http://dx.doi.org/10.1037/10402-020

[64] Eshet, I., Margalit, A. and Almagor, G. (1993) Short Family Therapy in Ambulatory Medicine (SFAT-AM): Treatment Approach in 10 - 15 Minute Encounters. Family Practice, 10, 178-187. http://dx.doi.org/10.1093/fampra/10.2.178

[65] Newman, P. and Peile, E. (2002) Valuing Learners’ Experience and Supporting Further Growth: Educational Models to Help Experienced Edult Learners in Medicine. British Medical Journal, 325, 200-202. http://dx.doi.org/10.1136/bmj.325.7357.200

[66] Hildon, Z., Allwood, D. and Black, N. (2012) Making Data More Meaningful: Patients’ Views of the Format and Content of Quality Indicators Comparing Health Care Providers. Patient Education and Counseling, 88, 298-304. http://dx.doi.org/10.1016/j.pec.2012.02.006

[67] Allen, J.K. and Dennison, C.R. (2010) Randomized Trials of Nursing Interventions for Secondary Prevention in Patients with Coronary Artery Disease and Heart Failure: Systematic Review. Journal of Cardiovascular Nursing, 25, 207-220. http://dx.doi.org/10.1097/JCN.0b013e3181cc79be

[68] Prilleltensky, I. (2005) Promoting Well-Being: Time for a Paradigm Shift in Health and Human Services. Scandinavian Journal of Public Health, 33, 53-60. http://dx.doi.org/10.1080/14034950510033381

[69] Specht, J.K., Taylor, R. and Bossen, A.L. (2009) Partnering for Care: The Evidence and the Expert. Journal of Gerontological Nursing, 35, 16-22. http://dx.doi.org/10.3928/00989134-20090301-09

[70] Shepperd, S., Lewin, S., Straus, S., Clarke, M., Eccles, M.P., Fitzpatrick, R., et al. (2009) Can We Systematically Review Studies That Evaluate Complex Interventions? PLoS Medicine, 6, e1000086.

http://dx.doi.org/10.1371/journal.pmed.1000086 